\title{
Rancang Bangun Alat Simulasi Wiper Otomatis Berbasis Microcontroller Sebagai Media Pembelajaran Wiper Electrical System Alat Berat
}

\author{
Abdul Halim ${ }^{*}$, Abdul Muis ${ }^{2}$, Abdul Halik ${ }^{3}$, Muhammad Saiful $^{4}$ \\ ${ }^{123}$ Program Studi Teknik Alat Berat Jurusan Teknik Mesin, Politeknik Negeri Samarinda, KALTIM, 75131, Indonesia \\ ${ }^{4}$ Alumni D3 Program Studi Teknik Alat Berat POLNES Coop. PT. Trakindo Utama, KALTIM, 75131, Indonesia
}

\begin{tabular}{ll}
\hline \hline Article Info & ABSTRAK \\
\cline { 2 - 3 } $\begin{array}{l}\text { Article history: } \\
\text { Received : }\end{array}$ & $\begin{array}{l}\text { Wiper adalah perangkat yang digunakan untuk membersihkan air hujan dan partikel dari } \\
\text { kaca yang dapat menghalangi penglihatan dari operator alat berat ketika cuaca hujan. }\end{array}$ \\
March $02^{\text {nd }}, 2020$ & $\begin{array}{l}\text { Untuk membersihkan air hujan dari kaca, operator harus mengaktifkan switch wiper. } \\
\text { Ketika operator sedang fokus dalam pekerjaan sering kali operator lupa mengaktifkan } \\
\text { wiper atau mematikan wiper, hal tersebut dapat mengganggu konsentrasi operator }\end{array}$ \\
Revised : & $\begin{array}{l}\text { khususnya pada alat berat saat bekerja. Wiper otomatis merupakan perangkat yang } \\
\text { mendeteksi air hujan dengan bantuan raindrop sensor FC } 37 \text { untuk mengaktifkan motor } \\
\text { May } 15^{\text {th }}, 2020\end{array}$ \\
Accepted & $\begin{array}{l}\text { dengan nyaman bekerja ketika cuaca sedang hujan. Tujuan dari membuat alat simulasi } \\
\text { wiper otomatis berbasis mikrokontroler arduino uno R3 adalah sebagai media } \\
\text { May } 28^{\text {th }}, 2020\end{array}$ \\
pembelajaran sistim kelistrikan wiper aplikasi di alat berat. Hasil yang diperoleh dari \\
pengujian simulasi berdasarkan SOP yang telah dibuat dan berhasil bekerja dengan baik \\
tanpa problem.
\end{tabular}

Kata kunci: Simulasi, Wiper otomatis, Mikrokontroler, Alat berat

\begin{abstract}
ABSTRAK
A wiper is a device used to clean rainwater and particles from glass that can block the vision of heavy equipment operators during rainy weather. To clean rainwater from the glass, the operator must activate the wiper switch. When the operator is focused on work often the operator forgets to turn on the windshield wipers or turns off the windshield wipers, it can disturb the operator's concentration especially on the machine when working. Automatic wipers are devices that detect rainwater with the help of a raindrop sensor FC 37 to activate the wiper motor without the need to activate the switch. With this automatic wiper the operator can comfortably work when the weather is rainy. The purpose of making a microcontroller arduino ino R3 based automatic wiper simulation tool is as a learning media for wiper electrical system applications on heavy equipment. The results obtained from simulation testing based on the standard operating procedures that have been made and successfully work well without problems.
\end{abstract}

Keywords: Simulation, Automatic wiper, Microcontroller, Heavy equipment

Corresponding Author:

Abd. Halim

Department of Mechanical Engineering

Politeknik Negeri Samarinda,

Jl, Ciptomangunkusumo Kampus Gunung Lipan, Samarinda 75131, Indonesia

Email: halim72@polnes.ac.id 


\section{PENDAHULUAN}

Wiper adalah perangkat yang digunakan untuk membersihkan air hujan dan partikel dari kaca depan atau belakang yang dapat menghalangi penglihatan dari operator. Hampir semua kendaraan bermotor termasuk kereta api, pesawat terbang, perahu dan terkhususnya alat berat dilengkapi dengan wiper. Wiper pertama kali diperkenalkan oleh seorang bernama Mary Anderson, saat itu cara kerja wiper dengan memutar-mutar handle dari dalam kabin untuk menggerakkan karet wiper yang menempel di bagian luar kaca. Sebuah wiper umumnya terdiri dari lengan berputar di satu ujung dengan pisau karet. Pisau berayun bolak-balik diatas kaca untuk mendorong air dan puing-puing dari permukaan kaca. Selama ini untuk menentukan kecepatan putaran pembiasnya dilakukan dengan cara manual yaitu dengan switch manual menyesuaikan intensitas hujan yang turun. Hal tersebut dapat mengganggu konsentrasi operator khususnya pada alat berat saat bekerja.

Selain faktor kelelahan dan banyaknya tuas atau handle yang harus dioperasikan, kondisi hujan yang turun juga mengharuskan operator untuk menghidupkan wiper. Hal ini menyebabkan hilangnya konsentrasi operator dan dalam waktu yang singkat akan sangat berbahaya, kondisi ini diperparah dengan ukuran unit yang sangat besar dan intensitas hujan yang deras, sehingga operator tidak bisa melihat kondisi di depannya.

Dari permasalahan diatas, maka perlu dikembangkan suatu system hardware untuk melakukannya. Sistem ini menangkap kelembapan air hujan dengan sensor, kemudian secara otomatis data diproses di dalam mikrokontroller. Penggunaan mikrokontroller dikarenakan mikrokontroller saat ini banyak digunakan untuk kontrol sistem dan otomatisasi serta kemudahannya dalam diprogram.

Penelitian terkait dengan penggunaan jenis wiper dengan pengontrolannya yang berbeda beberapa tahun terakhir. Pembuatan Alat simulasi pada sistem kelistrikan wiper sebagai media pembelajaran di SMK [1], perbedaan dari penelitian sebelumnya adalah penulis pada sistem pengontrolan kerja wiper yang awalnya dikontrol secara manual, kemudian dibuat pengontrolan secara otomastis oleh sensor hujan (raindrop sensor) yang di kontrol oleh mikrokontroler. Pembuatan prototype pembersih otomatis solar panel, membuat sistem kendali intensitas debu dan waktu untuk kebutuhan alat pembersih otomatis solar panel, proses pembacaan menggunakan sensor debu dan modul RTC, untuk penggerak wiper menggunakan motor servo [2]. Penelitian yang sama tapi dengan obyek yang berbeda yaitu memanfaatkan sensor hujan untuk sistim jemuran pintar [3]. Begitupula sistem peringatan dini banjir menerapkan modul FC-37 [4] dan perancangan sebuah sistem monitoring pendeteksian hujan dan suhu berbasis sensor secara real time [5].

Berdasarkan latar belakang yang telah diuraikan, permasalahan yang akan diungkapkan dalam penelitian ini bagaimana desain dan program yang digunakan pada microcontroller dan cara menggerakan motor wiper secara otomatis dengan sensor yang digunakan sebagai alat simulasi pada electrical system wiper alat berat.

\section{Kajian Teoritis \\ Pengaplikasian Wiper Otomatis pada Alat Berat}

Alat berat didesain untuk melakukan pekerjaan konstruksi pembangunan, beberapa unit alat berat sering kali tidak beroperasi ketika cuaca dalam keadaan hujan deras. Sehingga pengaplikasian wiper otomatis ini digunakan pada beberapa alat berat yang memungkinkan bekerja ketika cuaca hujan yang tidak deras. Beberapa diantaranya adalah : track type tractor, excavator, bachoe loader, grader, semua merupakan machine yang digunakan untuk road maintenance dan penggalian untuk memindahkan material dari suatu area, dan menempatkannya ke tempat lain.

\section{Sistem Wiper}

Sistem wiper merupakan pembersih kaca yang berfungsi menghilangkan air hujan, salju, debu, lumpur, dan kotoran-kotoran lainnya yang menempel pada kaca, sehingga wiper termasuk komponen yang sangat penting untuk keselamatan operator, khususnya operator alat berat. Kaca pada unit alat berat diharapkan selalu dalam kondisi bersih, sehingga operator mempunyai visibilitas yang jelas terhadap kondisi jalan yang dilaluinya. Jika hal ini diabaikan, maka akan membahayakan keselamatan operator maupun orang lain. Oleh karena itu, unit alat berat yang dilengkapi dengan kaca depan harus dilengkapi wiper sebagai pembersih air hujan, untuk menghindari mengurangnya penglihatan ketika mengemudikan unit alat berat di jalan.

Wiper terdiri dari motor wiper, wiper link, wiper arm, dan wiper blade . kelengkapan lainnya pada wiper adalah intermitten ( bekerja lambat dan mempunyai jeda berselang). Wiper mempunyai beberapa komponen dapat dilihat secara langsung dan ada juga yang tidak dilihat secara langsung atau berada dibalik bodi unit. Komponenkomponen yang dapat dilihat secara langsung antara lain : wiper arm, wiper blade dan nozzle, sedangkan komponen-komponen yang tidak dapat dilihat secara langsung antara lain : motor wiper, dan wiper link. 


\section{Komponen Sistem Wiper}

Sistem wiper memiliki komponen dan sistem kelistrikan yang sederhana, sehingga nantinya akan mudah untuk mempelajari sistem wiper. Komponen-komponen pada sistem wiper secara umum antara lain sebagai berikut pada Tabel 1

Tabel 1. Komponen sistim wiper

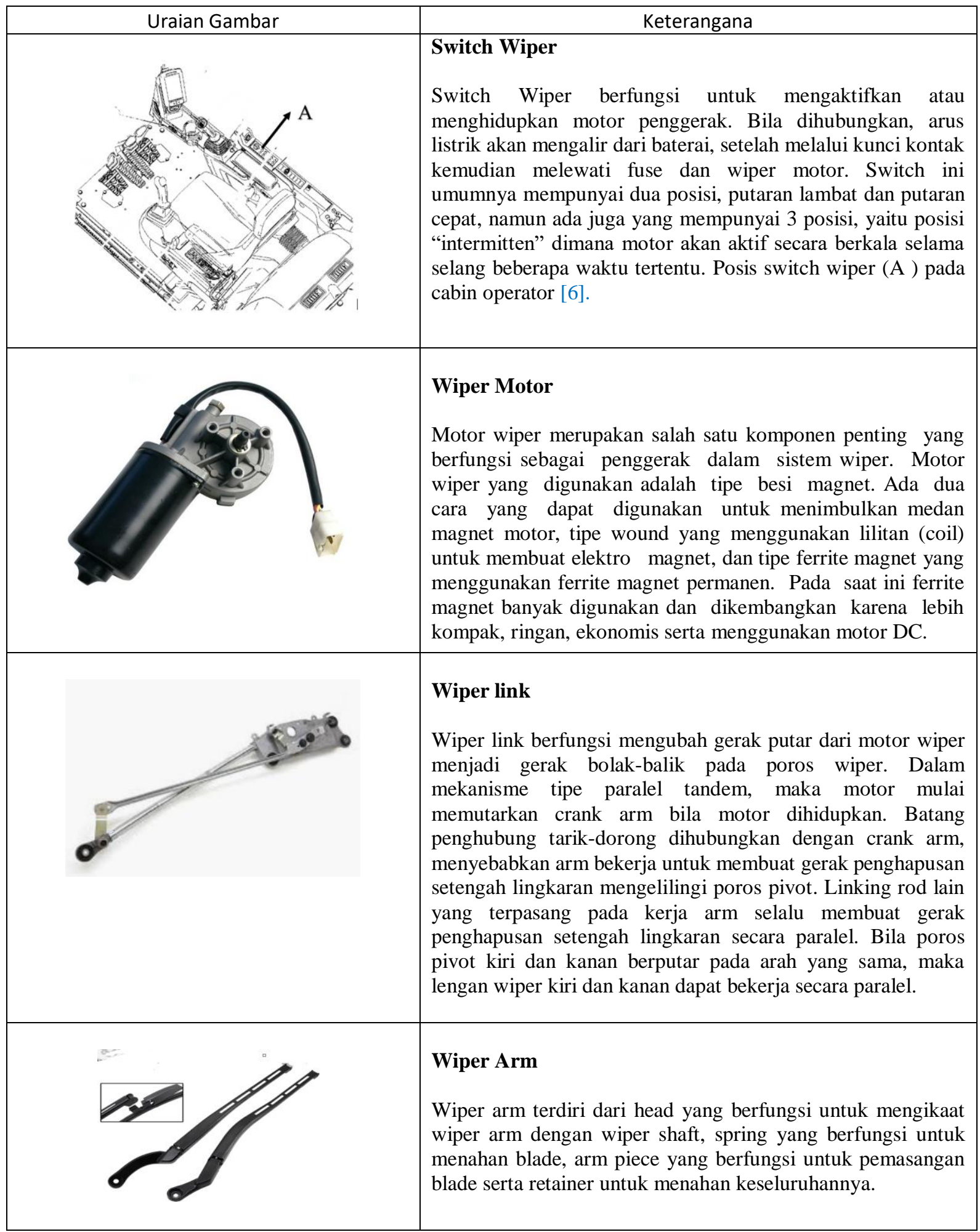




\begin{tabular}{|l|l|} 
Wiper Blade \\
$\begin{array}{l}\text { Wiper blade terdiri dari sebuah karet untuk membersihkan } \\
\text { permukaan kaca, suatu kombinasi dari leaf spring packing dan } \\
\text { beberapa lever, dan clip untuk memasang blade pada bagian } \\
\text { wiper arm. }\end{array}$ \\
\hline
\end{tabular}

\section{Arduino Uno R3}

Arduino Uno R3 [7] adalah papan mikrokontroler berdasarkan AT mega328P (datasheet). Alat ini memiliki 14 pin input / output digital 6 lainnya dapat digunakan sebagai output PWM, 6 input analog, kristal kuarsa 16 $\mathrm{MHz}$, koneksi USB, terminal listrik, header ICSP dan tombol reset. Alat ini berisi semua yang dibutuhkan untuk mendukung mikrokontroler. Cukup hubungkan ke komputer dengan kabel USB atau nyalakan dengan adaptor ACto-DC atau baterai untuk menjalankannya.

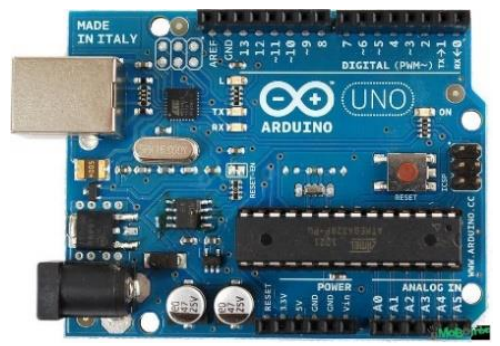

Gambar 1. Arduino Uno R3

ArduinoUno dapat diaktifkan melalui koneksi USB atau dengan catu daya eksternal. Sumber daya akan dipilih secara otomatis. Eksternal (non-USB) daya dapat berasal dari adaptor AC-DC atau baterai. Pada input adaptor AC-DC dapat dihubungkan dengan menancapkan sebuah konektor ukuran 2,1 mm dengan pusat-positif ke colokan yang telah tersedia pada board. Sedangkan penggunaan baterai dapat dimasukkan ke dalam header pin Gnd dan Vindari konektor daya. ArduinoUnoR3 dapat beroperasi pada pasokan eksternal 6 sampai 20 volt. Meskipun ArduinoUnoR3 dapat diberi tegangan kurang dari 7V, namun hal ini mengakibatkan ketidakstabilan. Kemudian ketika menggunakan tegangan lebih dari $12 \mathrm{~V}$, regulator tegangan akan panas dan merusak papan. Tegangan yang disarankan adalah 7 sampai 12 volt [8][9][10].

\section{Sensor Hujan FC 37 (FC 37 Raindrop)}

Raindrop sensor (sensor hujan) merupakan sebuah alat yang dapat mendeteksi hujan atau adanya cuaca hujan yang berada di sekitarnya, sensor ini dapat digunakan sebagai switch, saat adanya tetesan air hujan yang jatuh melewati raining board yang terdapat pada sensor, selain itu raindrop sensor dapat juga digunakan untuk mengukur intensitas curah hujan [11][12][13]. Output analog raindrop sensor digunakan untuk melakukan pendeteksian hujan, dengan kondisi nilai output sensor tinggi pada saat tidak mendeteksi hujan, sedangkan pada saat sensor mendeteksi hujan, nilai output sensor rendah. Gambar 2, memperlihatkan modul raindrop sensor [11].

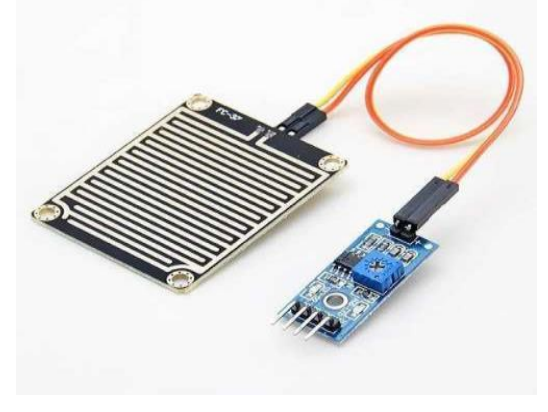

Gambar 2. Sensor hujan FC 37 
Fitur modul, Rain Board dan Control Board yang terpisah untuk kenyamanan yang lebih, indikator daya LED dan sensitivitas yang dapat disesuaikan dengan potensiometer, serta output data analog dapat digunakan untuk mendeteksi intensitas rintik air hujan.

\section{LCD ( Liquid Cristal Display ) 16 x 2}

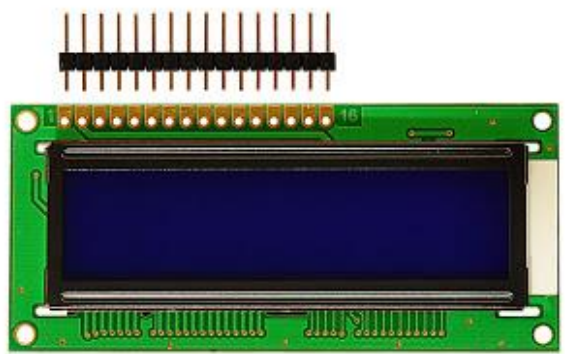

\section{Gambar 3. LCD 16 x 2}

Liquid cristal display adalah salah satu komponen elektronika yang berfungsi sebagai tampilan suatu data, baik karakter, huruf ataupun grafik. LCD adalah salah satu jenis display elektronik yang dibuat dengan teknologi CMOS logic yang bekerja dengan tidak menghasilkan cahaya tetapi memantulkan cahaya yang ada di sekelilingnya terhadap front-lit atau mentransmisikan cahaya dari back-lit. LCD (Liquid Cristal Display) berfungsi sebagai penampil data baik dalam bentuk karakter, huruf, angka ataupun grafik.

\section{Modul Relay Arduino}

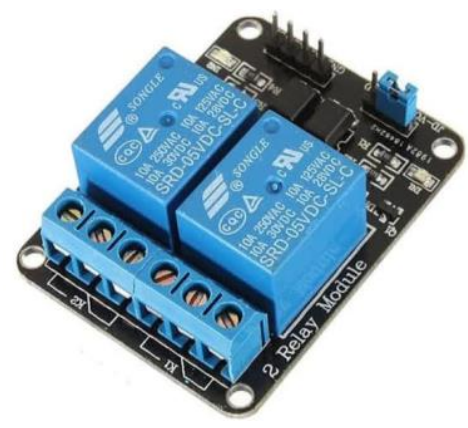

Gambar 4. Modul Relay

Relay berfungsi sebagai saklar otomatis. Prinsip kerja relay adalah elektromagnetik untuk merubah kondisi saklar yang dapat menghantarkan arus listrik dengan tegangan yang lebih tinggi. Ada dua macam jenis relay yaitu:

1. Normally Close (NC) dengan kondisi awaI saklar selalu berada pada posisi tertutup.

2. Normally Open (NO) dengan kondisi awaI saklar seIaIu berada pada posisi terbuka.

\section{METODOLOGI}

Untuk pembuatan alat simulasi wiper otomatis berbasis mikrokontroler ini ada beberapa tahap harus dilaksanakan. Gambar 3 memperlihatkan tahapan yang dilakukan dalam perancangan dan pembuatan alat, diawali dengan identifikasi masalah dan pengumpulan data, sampai pada pengujian alat apakah alat berfungsi sesuai dengan yang diinginkan atau tidak.

Untuk membuat program yang baik dan sesuai dengan tujuan penelitian, maka terlebih dahulu dibuat rancangan program dalam suatu diagram alir (flow chart) dari program yang dibuat agar alat bekerja berdasarkan program yang diinginkan. 


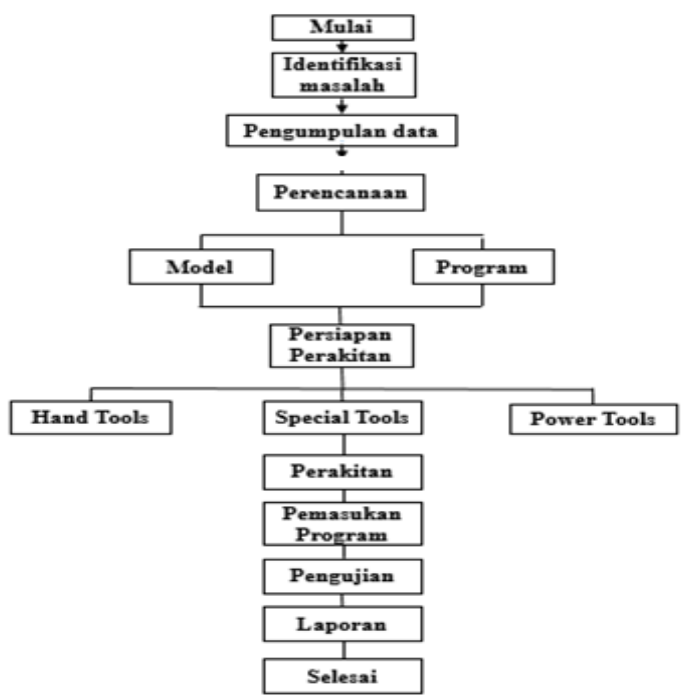

Gambar 5. Diagram Alir Penelitian

Setelah masalah telah di identifikasi kemudian masuk pada pengumpulan data. Pengumpulan data dilakukan dengan cara wawancara terhadap technician atau operator alat berat dan mencari referensi pada S.I.S, internet ataupun modul pembelajaran untuk memperluas wawasan untuk membuat sebuah alat simulasi. Kemudian melakukan perencanaan dengan cara mempersiapkan bahan pada tabel 2 dan peralatan yang dipelukan pada tabel 3 untuk proses pembuatan alat simulasi.

Tabel 2. Bahan-bahan Alat simulasi

\begin{tabular}{|c|c|c|c|}
\hline No. & Bahan & Jumlah & Satuan \\
\hline 1 & Besi hallow & 10 & Meter \\
\hline 2 & Acrylic & $100 \times 200$ & Centi meter \\
\hline 3 & Power supply 12 Volt & 1 & Buah \\
\hline 4 & Motor wiper & 1 & Buah \\
\hline 5 & Relay DC 12 Volt & 1 & Buah \\
\hline 6 & Roda frame & 4 & Buah \\
\hline 7 & Arduino uno R3 & 1 & Grup \\
\hline 8 & Sensor hujan & 1 & Buah \\
\hline 9 & Kotak power supply & 1 & Buah \\
\hline 10 & Selang & 2 & Meter \\
\hline 11 & Water pump & 1 & Buah \\
\hline 12 & Switch & 4 & Buah \\
\hline 13 & Baut dan mur & 20 & Buah \\
\hline 14 & Pilox hitam & 1 & Buah \\
\hline 15 & Rivet & 1 & Pack \\
\hline 16 & High Preasure Laminate & $100 \times 200$ & Centi meter \\
\hline 17 & Lem rajawali & 1 & Buah \\
\hline 18 & Besi talang air & 1 & Meter \\
\hline
\end{tabular}


Tabel 3. Peralatan pembuatan alat simulasi wiper

\begin{tabular}{|c|c|c|c|}
\hline NO & Peralatan & Jumlah & Satuan \\
\hline 1. & Laptop & 1 & Buah \\
\hline 2. & Solder & 1 & Buah \\
\hline 3. & Heatshrink & 1 & Buah \\
\hline 4. & Isolasi hitam & 1 & Buah \\
\hline & Kabel hitam dan merah & 5 & Meter \\
\hline 5 & Lem tembak & 5 & Buah \\
\hline 6 & Elektroda & 1 & Pack \\
\hline 7 & Gerinda & 1 & Buah \\
\hline & Bor listrik & 1 & Buah \\
\hline 8 & Las listrik & 1 & Buah \\
\hline 9 & Measuring tape 5 meter & 1 & Buah \\
\hline
\end{tabular}

Desain dari alat simulasi pada gambar 4 perlu dibuat untuk mempermudah dalam proses perakitan alat, proses desain ini menggunakan sketchup 2017.
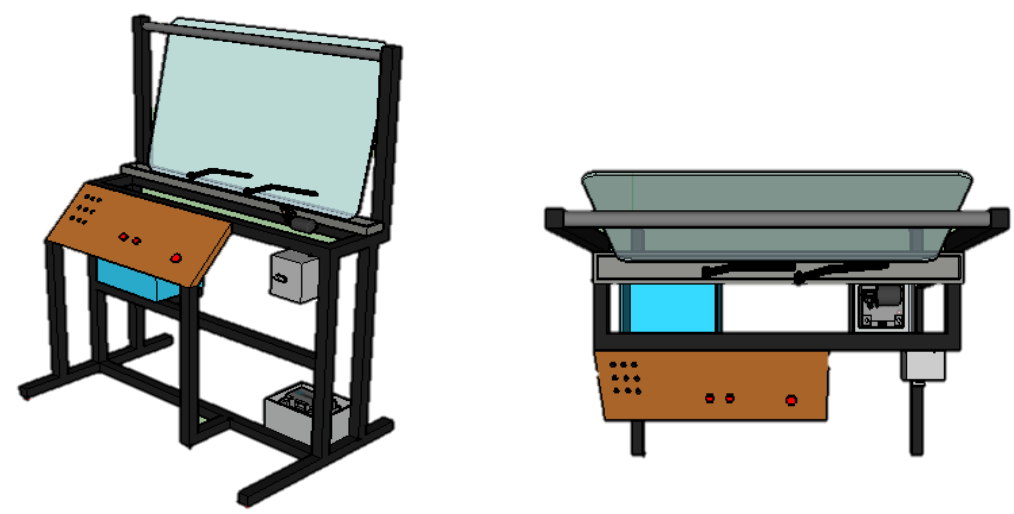

Gambar 6. Desain alat Wiper otomatis

Untuk rangkaian sistem arduino komponennya meliputi arduino uno, regulator, relay,sensor hujan, dan LCD , pada gambar dibawah merupakan rangkaian sistem kerja wiper otomatis.

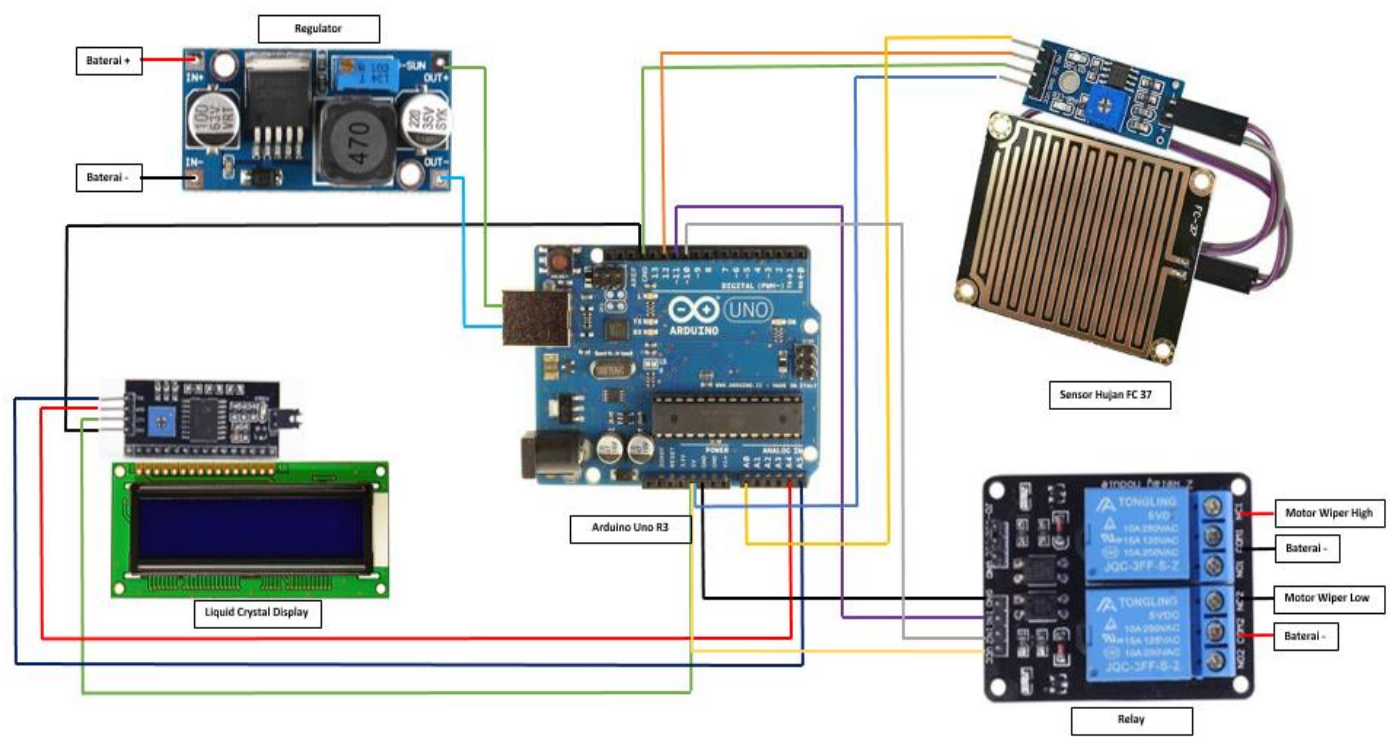

Gambar 7. Rangkaian arduino dan sensor hujan 


\section{HASIL DAN PEMBAHASAN}

Hasil dari proses pembuatan dan pemrograman alat wiper otomatis ini berupa proses pengetesan alat secara mode manual dan mode otomatis. Proses ini dilakukan untuk membandingkan sistem kerja wiper yang masih di kontrol secara manual menggunakan switch dan otomatis menggunkan sensor hujan untuk menggerakan motor wiper. Untuk pengontrolan secara manual, wiper digerakan hanya dengan 2 speed, yaitu speed 1 dan speed 2 untuk menggerakan motor wiper. Sedangan pengontrolan secara otomatis wiper motor bekerja ketika sensor hujan menangkap air hujan yang di dapat sebesar $20 \%$ yang mengakibatkan motor wiper akan bekerja dengan sendirinya. Ketika air hujan yang di terima sensor kurang dari $20 \%$ maka motor wiper akan berhenti dengan sendirinya. Untuk hujan yang di alirkan pada sensor hujan alat ini dibuat sebuah hujan buatan dengan tanki air pada gambar 6 yang di alrkan oleh water pump menuju kaca.

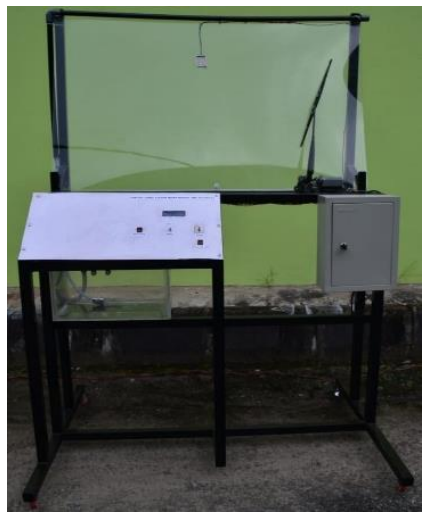

Gambar 8. Alat simulasi

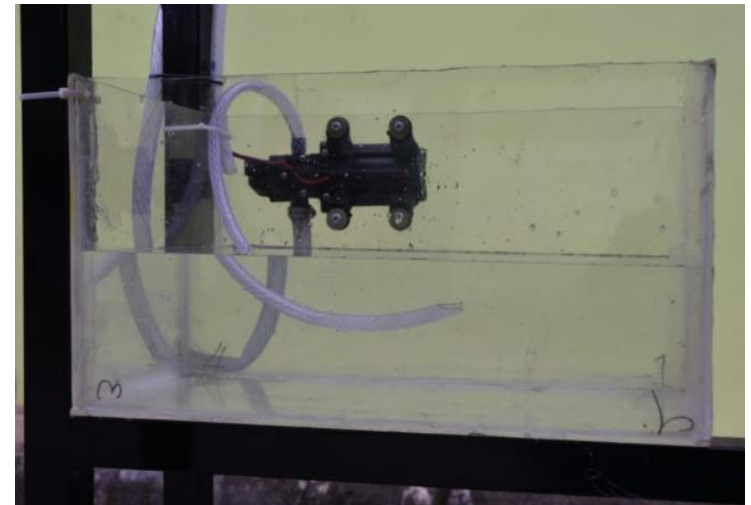

Gambar 9. Tanki air

Pada mode otomatis wiper akan bekerja ketika sensor hujan membaca kelembapan air sebesar $20 \%$ yang terbaca pada $L C D$ Wiper $O N$ dengan tingkat rain level berbeda untuk menggerakan motor wiper, ketika dibawah $20 \% L C D$ akan terbaca rain sensing sehingga motor wiper tidak akan bekerja atau berhenti.
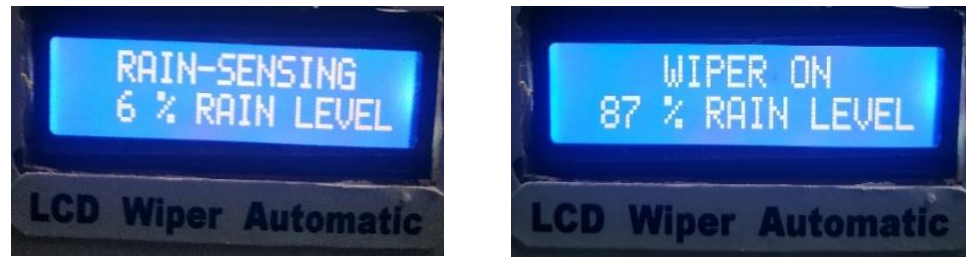

Gambar 10. LCD Wiper Automatic

Pengujian berikutnya adalah pengukuran pada motor wiper dengan tujuan berapa daya yang diperlukan untuk menggerakan motor wiper dengan kapasitas power supply 12 volt 30 ampere. Sehingga jika alat ini dipasang pada unit alat berat komponen seperti aksesoris lamp, horn, dan lainnya tidak terganggu atau terbebani.

Tabel 3. Hasil pengukuran motor wiper

\begin{tabular}{|c|c|c|c|}
\hline \multirow{2}{*}{ Percobaan } & \multicolumn{3}{|c|}{ Motor Wiper } \\
\cline { 2 - 4 } & Tegangan (Volt) & Arus (Ampere) & Daya(Watt) \\
\hline Speed 1 & $9,2 \mathrm{~V}$ & $0,5 \mathrm{~A}$ & $4,6 \mathrm{~W}$ \\
\hline Speed 2 & $11,04 \mathrm{~V}$ & $0,7 \mathrm{~A}$ & $7,7 \mathrm{~W}$ \\
\hline
\end{tabular}

Pengukuran diatas dapat disimpulkan power supply dengan kapasitas 12 volt 30 ampere dengan daya 360 watt, dapat menggerakan motor wiper dengan speed 1 menggunkan 4,6 watt dan speed 2 menggunakan 7,7 watt sehingga jika digunakan pada batterai unit alat berat daya yang digunakan cukup untuk menggerakan motor wiper. 
Pengukuran selanjutnya dilakukan dari power supply ke komponen arduino untuk mengecek berapa arus dan tegangan yang disuplai untuk mengaktifkan sistem kerja wiper otomatis.

1. Power supply ke regulator $=11,59$ Volt

Ketika switch mode manual tegangan yang disuplai dari power supply ke regulator sebesar 11,59 V untuk mengaktifkan motor wiper dan water pump.

2. Regulator ke Arduino $=9,25$ Volt

Ketika Switch mode otomatis tegangan yang di suplai dari power supply menuju regulator akan diturunkan sebesar 9,25 V, untuk disuplai menuju arduino dan mengaktifkan mode wiper otomatis.

Sensor hujan bekerja ketika tegangan naik ataupun turun, yang kemudian dikirimkan oleh sensor hujan menuju modul sensor hujan pada arduino kemudian data akan diolah arduino untuk mengaktifkan relay menuju motor wiper.

1. Ketika sensor tidak terkena air dengan presentasi air $8 \%$ maka tegangan yang di hasilkan adalah 3,7 Volt

2. Ketika sensor terkena air dengan presentasi air $87 \%$ maka tegangan yang di hasilkan adalah 1,5 Volt

\section{KESIMPULAN}

Setelah melakukan perancangan dan perakitan terhadap alat sistem wiper otomatis yang menggunakan arduino dan sensor hujan sebagai pengontrolan untuk menggerakan motor wiper dan juga telah dilakukannya proses pengujian alat serta pengukuran terhadap tegangan, arus, dan resistansi pada alat tersebut baik dalam kondisi mode wiper manual ataupun mode wiper otomatis maka dapat ditarik kesimpulan bahwa :

1. Untuk mengoperasikan wiper dalam mode manual hanya menggunakan 2 speed, yaitu speed 1 dan speed 2. Mode manual ini di buat sebagai contoh pada unit yang masih menggunkan swith secara manual untuk mengaktifkan wiper.

2. Untuk mengoperasikan wiper dalam mode otomatis, motor wiper akan bekerja menggerakan wiper blade dengan sendirinya jika air hujan membasahi sensor hujan dan mencapai tingkat kelembapan sebesar $20 \%$ untuk menggerakan wiper motor. Jika sensor hujan menerima air dengan kelembapan di bawah $20 \%$, atau 10 $\%$, wiper motor akan mati dengan sendirinya tanpa perlu mematikan switch wiper motor.

3. Sistem wiper otomatis bekerja karena adanya tegangan yang dikirimkan oleh sensor hujan menuju arduino, denga hasil pengukuran pada sensor ketika sensor membaca kelembapan di bawah $20 \%$ dengan tegangan 3,7 volt maka relay akan normally open, dan ketika sensor membaca kelembapan di atas $20 \%$ dengan tegangan tegangan 1,5 volt maka relay akan normally close untuk mengaktifkan wiper motor.

\section{UCAPAN TERIMA KASIH}

Terima kasih diucapkan kepada pihak Manajemen Workshop Program Studi Teknik Alat Berat Jurusan Teknik Mesin Politeknik Negeri Samarinda

\section{DAFTAR PUSTAKA}

[1] Nurhadi Wijaksono, "Media Pembelajaran Sistem Kelistrikan Wiper Dan Washer Di SMK Negeri 1 Sedayu", Tugas Akhir, Universitas Negeri Yogyakarta, 2015.

[2] M. R. Wira Kesuma, E. Apriaskar, and Djunaidi, "Rancang Bangun Sistem Pembersih Otomatis Pada Solar Panel Menggunakan Wiper Berbasis Mikrokontroler," Jurnal Ilmiah Elektronika, vol. 19, no. 1, 2020

[3] T. M. Banjarnahor, Sumarno, B. E. Damanik, I. Gunawan and . I. O. Kirana, "Jemuran Pintar Dengan Sensor Ldr, Sensor Hujan, Sensor Suhu Dan Sensor KecepatanAngin Berbasis Arduino," Jurnal Building of Informatics, Technology and Science (BITS), vol. 1, no. 2, pp. 75-81, 2019.

[4] S. Mahardika, W. Kurniawan and F. Bakhtiar, "Implementasi Sistem Real Time untuk Pendeteksi Dini Banjir berbasis ESP8266 dan Weather API," Jurnal Pengembangan Teknologi Informasi dan Ilmu Komputer, vol. 3, no. 8, pp. 8238-8247, 2019. 
[5] Muhamad Yusvin Mustar, R. O. W, Implementasi Sistem Monitoring Deteksi Hujan dan Suhu Berbasis Sensor Secara Real Time (Implementation of Rain Detection and Temperature Monitoring System Based on Real Time Sensor)," Semesta Teknika, vol. 20, no.1, pp. 20-28, 2017

[6] Depart. Training Center, "Fundamental of Electrical System," PT Trakindo Utama, Cileungsi, Bogor (2008).

[7] G. Wohingati, and A. Subari, "Alat Pengukur Detak Jantung Menggunakan Pulsensor Berbasis Arduino Uno R3 Yang Diintegrasikan Dengan Bluetooth," Gema Teknologi, vol. 17, no. 2, Aug. 2015. https://doi.org/10.14710/gt.v17i2.8919

[8] Wicaksono, MF, Hidayat," Mudah Belajar Mikrokontroler Arduino," Bandung: Informatika 2017.

[9] Francisco, A. R. L,'IDE Arduino," Journal of Chemical Information and Modeling, 53(9), 1689-1699, 2013

[10] Kholilah, I., \& Al Tahtawi, A. R., "Aplikasi Arduino-Android untuk Sistem Keamanan Sepeda Motor., Jurnal Teknologi Rekayasa, 1(1), 53, 2017.

[11] Katyal, A., Yadav, R., \& Pandey, M," Wireless Arduino Based Weather Station," International Journal of Advanced Research in Computer and Communication Engineering, vo. 5, no. 4, 2016.

[12] Sulastri, R.," Prototype Kendali Buka/Tutup Dan Penyiraman Tanaman Cabai Berbasis Mikrokontroler Dan SMS Gateway," Eprint.polsri.ac.id, Politeknik Negeri Sriwijaya, 2016.

[13] Unsal, E., Milli, M., Aktaş, Ö., \& Çebi, Y.," Low-cost Wireless Sensor Networks for Greenhouse Monitoring Applications," Presented at the 4th International Conference on Advanced Technology \& Sciences (ICAT'Rome), 2016 